\title{
The Last Possible Outposts for Life on Mars
}

\author{
Alfonso F. Davila ${ }^{1,2}$ and Dirk Schulze-Makuch ${ }^{3,4}$
}

\begin{abstract}
The evolution of habitable conditions on Mars is often tied to the existence of aquatic habitats and largely constrained to the first billion years of the planet. Here, we propose an alternate, lasting evolutionary trajectory that assumes the colonization of land habitats before the end of the Hesperian period ( $c a .3$ billion years ago) at a pace similar to life on Earth. Based on the ecological adaptations to increasing dryness observed in dryland ecosystems on Earth, we reconstruct the most likely sequence of events leading to a late extinction of land communities on Mars. We propose a trend of ecological change with increasing dryness from widespread edaphic communities to localized lithic communities and finally to communities exclusively found in hygroscopic substrates, reflecting the need for organisms to maximize access to atmospheric sources of water. If our thought process is correct, it implies the possibility of life on Mars until relatively recent times, perhaps even the present. Key Words: Life-Mars-Evolution—Desert—Land ecosystems—Deliquescence. Astrobiology 16, 159-168.
\end{abstract}

\section{Introduction}

$\mathbf{H}$ ABITABILITY MODELS of Mars often tie the potential for life to the existence of aquatic habitats such as lakes or oceans (e.g., McKay and Davis, 1991). Along these lines, current and planned robotic missions mainly focus on the study of sedimentary deposits formed in aquatic environments billions of years ago. The discovery of ancient lake sediments deposited in a geochemical environment compatible with life (Grotzinger et al., 2014), together with the certainty that such environments were widespread during the Noachian and Hesperian periods (e.g., Bibring et al., 2006; Mustard et al., 2008; Ehlmann and Edwards, 2014), has so far validated this strategy.

However, this vision of habitability is incomplete, and the above paradigm ought to be reconsidered because the fate of an early martian biosphere was not necessarily tied to the duration of aquatic habitats. An alternative evolutionary trajectory would have opened with the colonization of land, at which point a portion of the martian biosphere would have become dependent solely on atmospheric sources of water. In this synthesis paper, we consider this second trajectory by addressing two aspects of the problem: (1) the probability that early life on Mars would have colonized land and (2) land ecosystems' response to increasing dryness. We focus our analysis on forms of life on, or near, the surface that ultimately rely on atmospheric sources of water. The possibility of life in the deep subsurface is not discussed.

\section{The Colonization of Land}

The three domains of life on Earth contain both aquatic and terrestrial groups, but among the prokaryotes there appears to be a major evolutionary group with a common ancestor on land, the so-called Terrabacteria, which includes members of the cyanobacteria, the Gram-positive phyla, and the Chloroflexi and Deinococcus-Thermus (Battistuzzi and Hedges, 2009). Representatives of this group possess specific adaptations to land environments such as resistance to desiccation, high salinity, and high UV radiation. Phylogenetic, cytological, and environmental data suggest that the Terrabacteria and Hydrobacteria could have diverged as early as $3.54 \mathrm{Ga}$ (Battistuzzi and Hedges, 2009), relatively fast after the origin of life. To date, possible evidence of land ecosystems have been found in late Mesoproterozoic to early Neoproterozoic paleosols (ca. 1.2-1 billion years ago) (Prave, 2002) in 2.9-2.7 billion-year-old ephemeral ponds (Rye and Holland, 2000) and alluvial sequences, some of which bear microfossils (Hallbauer and van Warmelo, 1974; Mossman et al., 2008), and in paleosols that formed between 2.7 and 2.6 billion years ago (Watanabe et al., 2000). Considering that the geological record of land environments is sparse,

\footnotetext{
${ }^{1}$ Carl Sagan Center at the SETI Institute, Mountain View, California, USA.

${ }^{2}$ NASA Ames Research Center, Moffett Field, California, USA.

${ }^{3}$ School of the Environment, Washington State University, Pullman, Washington, USA.

${ }^{4}$ Center of Astronomy and Astrophysics, Technical University Berlin, Berlin, Germany.
}

(C) Alfonso F. Davila and Dirk Schulze-Makuch, 2016; Published by Mary Ann Liebert, Inc. This Open Access article is distributed under the terms of the Creative Commons Attribution Noncommercial License (http://creativecommons.org/licenses/by-nc/4.0/) which permits any noncommercial use, distribution, and reproduction in any medium, provided the original author(s) and the source are credited. 
the colonization of land might have occurred earlier than what the fossil record suggests.

Resistance to desiccation, high salinity, and UV radiation, the trademarks of the Terrabacteria, are also survival adaptations of aquatic microorganisms in coastal areas, such as those that inhabit benthic mats periodically exposed to airdrying and UV radiation during cycles of evaporation and flooding (e.g., Garcia-Pichel, 1998; Pattanaik et al., 2007; Beraldi-Campesi, 2013). Perhaps not surprisingly, the cyanobacteria, a deeply rooted taxonomic group often found in aquatic environments, include some of the most desiccationresistant organisms known, which are adapted to survive in the driest regions on Earth (Friedmann, 1980; Friedmann and Ocampo-Friedmann, 1995; Warren-Rhodes et al., 2006; Pointing and Belnap, 2012; Wierzchos et al., 2012b). The above suggests that the colonization of land could be a relatively straightforward evolutionary step once aquatic habitats are established.

On Mars, the established existence of aquatic habitats during the late Noachian about 3.8 billion years ago (Grotzinger et al., 2014) and the inferred existence of aquatic environments at the end of the Hesperian $c a .3$ billion years ago (McKay and Davis, 1991), together with the cumulative evidence of episodic aquatic environments during the Early Amazonian (Fairén et al., 2009; Rodríguez et al., 2014, 2015), suggest that an early martian biosphere could have had sufficient time to colonize land, assuming a similar pace of colonization as life on Earth. But contrary to Earth, most of the surface of Mars was emerged land even when liquid water was abundant (Carr and Head, 2015). The inferred existence of tens of thousands of crater lakes in the martian southern highlands, and possibly a large northern ocean, implies a potentially large net shoreline area with shallow aquatic environments that could have propelled the emergence of land microorganisms. The absence of a magnetic field since the late Noachian (Acuna et al., 1998; Carr and Head, 2010) along with the continued decline in atmospheric pressure in the first 2 billion years (Lammer et al., 2013) would have exerted strong selective pressures on martian organisms to adapt to desiccation, UV radiation, and high salinity, thus paving the way for the colonization of land. After the colonization of land, long-term habitability on Mars would no longer have been tied to the existence of aquatic environments but to atmospheric sources of water. This could have significantly expanded the martian habitability window beyond the Hesperian period.

\section{Ecological Transitions in Dryland Ecosystems}

Important lessons regarding the possible adaptations of land ecosystems to increasing dryness can be learned from the study of life in dryland environments on Earth. Drylands are one of the largest terrestrial biomes, and more than 35\% of Earth's land mass is permanently or seasonally arid (Pointing and Belnap, 2012). Dryland ecosystems encompass a broad hydrological range, typically measured as the Aridity Index (AI), defined as the ratio of mean annual precipitation to potential evapotranspiration. Based on the AI scale, drylands are categorized as semiarid $(0.20<\mathrm{AI}<0.50)$, arid $(0.05<\mathrm{AI}$ $<0.20$ ), and hyperarid (AI <0.05). Research conducted over the past 40 years suggests that there is a predictable pathway of ecological change with increasing dryness, driven by the need of organisms to maximize exposure to liquid water during sporadic wet events.

Many desert organisms are capable of desiccation tolerance, the ability to dry up without dying (Potts, 1994; Alpert, 2005) and to resume metabolic activity quickly after rehydration, even after years of complete desiccation (e.g., Potts, 1994; Proctor et al., 2007). In arid regions, these poikilohydric microorganisms colonize the top few centimeters of soil and rock substrates between a patchy vegetation cover (Belnap and Lange, 2003; Pointing and Belnap, 2012), and relatively complex microbial communities largely sustained by phototrophic organisms can develop as biological soil crusts (BSC) (Fig. 1A). In arid deserts, BSC can cover up to $70 \%$ of the total soil surface (Belnap and Lange, 2003), leading to relatively high concentrations of organic carbon (OC) that is recycled relatively fast, within decades to several centuries (Amundson, 2001).

However, a significant ecological collapse occurs in soils at the transition from arid to hyperarid conditions (Fig. 2). This transition signals a dramatic reduction in vegetation cover, which becomes almost entirely confined to ephemeral runoff channels (washes) and episodic and transient blooms that follow rare rainfall events. Biological soil crusts in hyperarid soils become increasingly fragmented or patchy, and there is a significant decline of both cell abundance and species richness (Pointing et al., 2007; Pointing and Belnap, 2012; Crits-Christoph et al., 2013). Soil microbial communities and BSC in both temperate and cold hyperarid environments become discontinuous and are gradually replaced by regolith and desert pavements (Pointing and Belnap, 2012; Colesie et al., 2013). This is reflected in the distribution of soil OC and biomass (Fig. 2B), which fall to the lowest levels found anywhere on Earth $\left(\mathrm{ca} .10^{3}\right.$ to $10^{5}$ cells $\mathrm{g}^{-1}$ soil), concurrent with an increase in mean residence time of soil OC to tens of thousands of years (Ewing et al., 2008).

In these hyperarid environments, soil communities are largely replaced by rock-inhabiting (lithobiontic) communities (e.g., Friedmann, 1980; Pointing and Belnap, 2012; Wierzchos et al., 2012b). Lithobiontic communities comprise epilithic microorganisms that colonize the surface of rocks, hypolithic microorganisms that colonize the underside of translucent substrates such as quartz rocks and gypsum crusts (Fig. 1C), and endolithic microorganisms that colonize the interior of porous substrates such as sandstone rocks and salt crusts (Fig. 1D). The colonization of lithic substrates is a direct response to water deficit. Hypolithic and endolithic habitats extend the range of conditions under which liquid water can occur, and at the same time, surface tensions in the rock matrix slow the evaporation of water and thus prolong access to moisture after a wetting event. This is critical for microbial communities whose long-term survival hinges on their capacity to sustain a net positive carbon balance in the course of repeated cycles of wetting and drying (Alpert and Oechel, 1985; Friedmann et al., 1993; Coe et al., 2012). In temperate deserts, this is not trivial, because liquid water often occurs during the night, when respiration, but not photosynthesis, can occur. The net flux of $\mathrm{CO}_{2}$ is negative in these first hours of dark metabolic activity and can only be balanced via photosynthesis if water still persists in the early morning (Noy-Meir, 1973; Alpert and Oechel, 1985; Alpert, 2005). Due to their water retention, lithic substrates expand the window for photosynthesis 

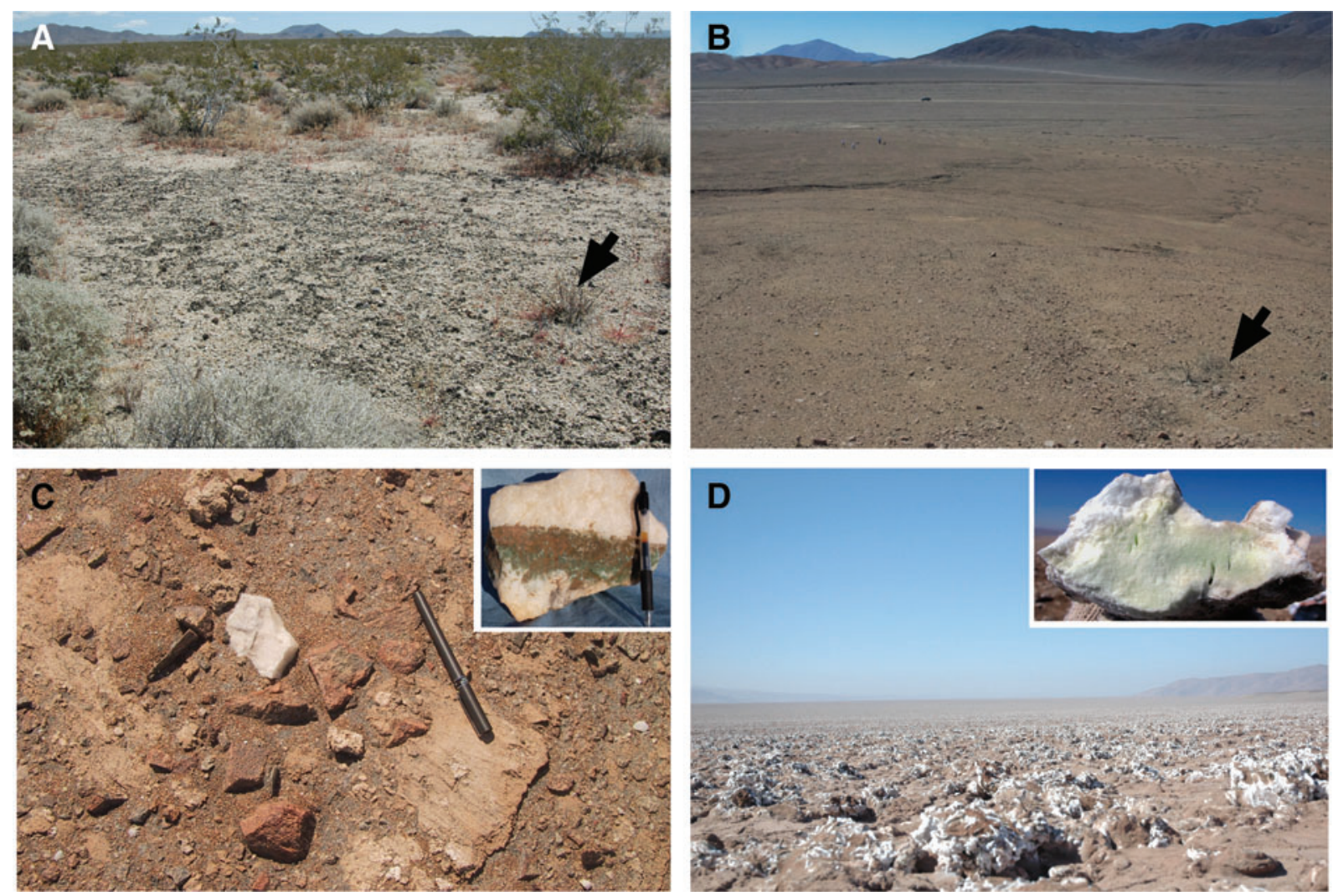

FIG. 1. Successions of dryland ecosystems with increasing dryness. (A) Vegetated arid site in the Mojave Desert, with a continuous cover of BSC. (B) Nonvegetated hyperarid site in the Atacama Desert devoid of BSC. (C) Hypolithic microbial community under a translucent quartz stone in the hyperarid Namib Desert. (D) Microbial community inside a hygroscopic salt crust in the hyperarid core of the Atacama Desert. Black arrows in A and B point to features of similar size, for scale. (Color graphics available at www.liebertonline.com/ast)

in the morning and enable the communities to balance respiration with carbon fixation. The protected lithic microenvironment also provides shelter against erosion and wind, amelioration of extreme temperature changes, and shielding against UV radiation (Friedmann, 1980). Colonized lithic habitats are found in all deserts, including regions once considered to be too dry for life (Friedmann, 1982; WarrenRhodes et al., 2006; Wierzchos et al., 2006, 2012b; Pointing et al., 2009; Cary et al., 2010; Khan et al., 2011; Pointing and Belnap, 2012). Despite the diversity of lithic habitats and the broad range of dryland environments where they are found, community structure in hypolithic and endolithic habitats is remarkably similar, although the composition of the community might be very different (Pointing et al., 2007). A key concept with regard to lithic habitats is that the physical properties of the substrate generate local habitable conditions in environments that might otherwise be too harsh for life (Friedmann and Ocampo-Friedmann, 1984).

Yet there are also trends of extinction within lithic habitats with increasing dryness. For example, in the Dry Valleys of Antarctica endolithic microbial communities are found primarily in the interior of south-facing sandstone rocks and cliffs, where microorganisms take advantage of meager snowmelt that percolates into the rock during warm summer days (Friedmann, 1982; McKay and Friedmann, 1985). However, the sandstone endolithic community in the Dry Valleys appears to be at the brink of extinction, and in some of the coldest and driest valleys the endolithic colonies are largely fossilized (Friedmann et al., 1994; Wierzchos et al., 2004, 2005; Sun, 2013). A similar trend of extinction is observed in hypolithic habitats with decreasing rainfall in hyperarid deserts. Hypolithic colonization of translucent rocks is typically $100 \%$ (i.e., all suitable rocks are colonized) in semiarid regions, dropping to $<50 \%$ in arid areas and to $<1 \%$ in hyperarid regions, where the hypolithic habitat becomes practically nonexistent (Warren-Rhodes et al., 2006, 2007) (Fig. 2A) except in local areas of recurrent fog (Azúa-Bustos et al., 2011). The disappearance of hypolithic colonies with diminishing rainfall is mirrored by epilithic lichens (Wierzchos et al., 2011), despite the fact that some can supplement liquid water with water vapor and restore photosynthesis with high $(>75 \%)$ humidity only (Lange, 1993).

At the driest end of hyperaridity, where soils and most lithic substrates can no longer sustain active biology (e.g., Warren-Rhodes et al., 2006; Ewing et al., 2008; CritsChristoph et al., 2013), relatively complex and abundant communities of autotrophic and heterotrophic bacteria and archaea (de los Ríos et al., 2010; Robinson et al., 2015) are still found inside porous, hygroscopic salt crusts (Wierzchos et al., 2006) (Fig. 1D). The communities inside the salt nodules use liquid brines that form in the interior of the salt substrate from the vapor phase via deliquescence and capillary condensation (Davila et al., 2008, 2013; Wierzchos et al., 2012a). Because the salt substrate retains water 
Arid Semiarid

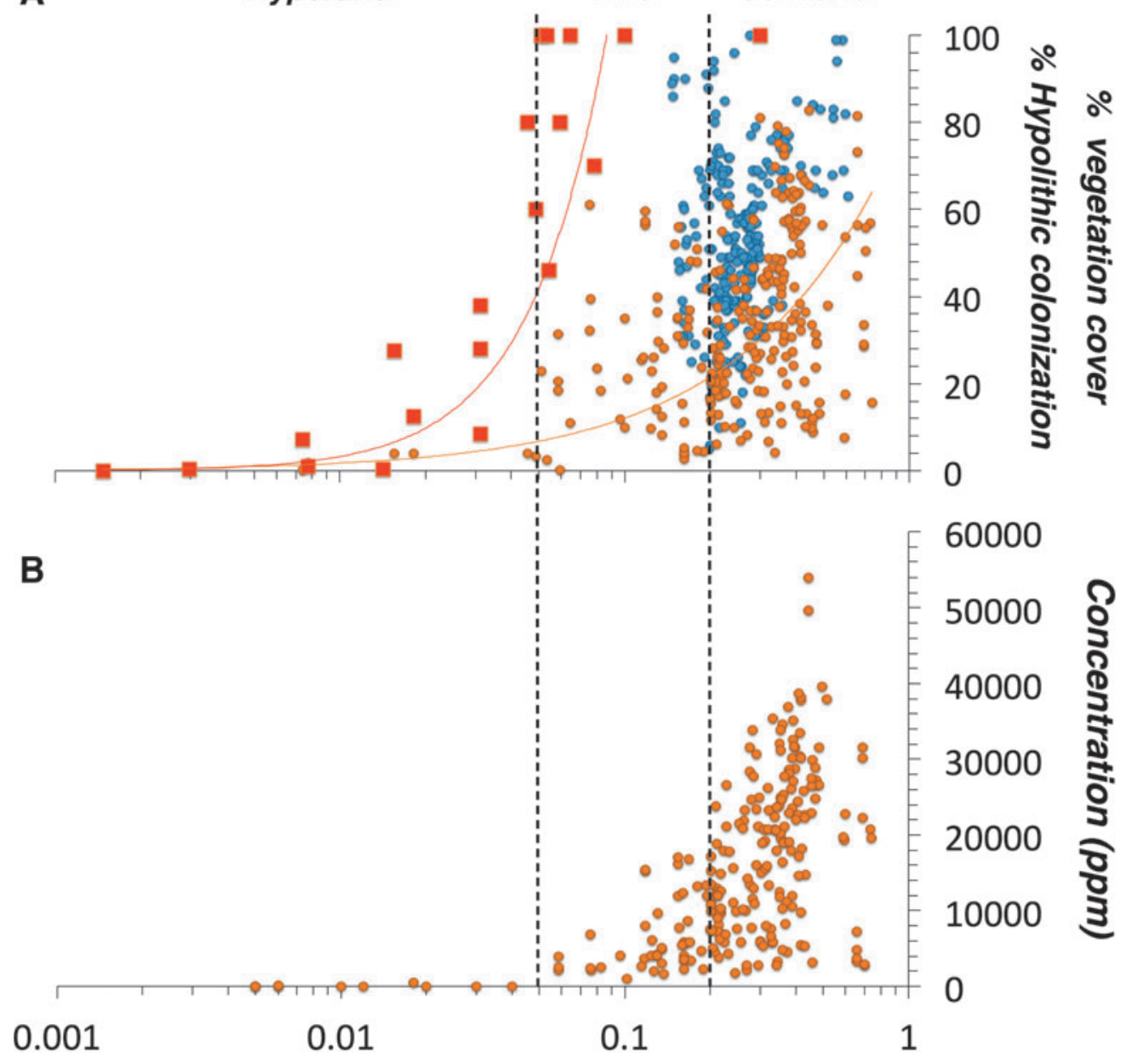

\section{Aridity Index}

FIG. 2. (A) Percent vegetation cover (dots) and percent hypolithic colonization (squares) as a function of aridity (expressed as AI). Blue dots are actual field observations (data from Delgado-Baquerizo et al., 2013). Orange dots are from satellite data. Percent hypolithic colonization data was obtained from Allen (1997), Warren-Rhodes et al. (2006, 2007, 2013), Khan et al. (2011), Al-Thani (2014) and references therein. (B) Soil OC concentration as a function of aridity (data from Delgado-Baquerizo et al., 2013).

efficiently, cyanobacteria inside the salt nodules can fix $\mathrm{CO}_{2}$ for days after a wetting event (Davila et al., 2015), and the community is capable of carbon cycling rates in timescales of decades (Ziolkowski et al., 2013) even in the absence of atmospheric precipitation. Such deliquescent substrates provide a minimalistic habitat for survival under extremely dry conditions, and in the driest place on Earth they likely represent the last available habitat for life.

\section{The Late-Stage Evolution of Land Ecosystems on Mars}

The transition from widespread edaphic communities to localized lithic communities and finally to communities exclusively found in hygroscopic substrates reflects the need for land organisms to maximize access to atmospheric sources of water. We propose that, if life colonized martian land, a similar sequence of ecological transitions would have occurred as the planet became increasingly dry (Fig. 3).
First, relatively diverse microbial communities would have been widespread in the top centimeters of the regolith, with metabolic cycles tuned to episodes of rainfall, dew, fog, snow, or glacier melt. Pigmentation and community structure could be adequate solutions for UV protection, and proximity to the surface would have granted access to sunlight and an abundant carbon source in the atmosphere. These communities would likely be comprised of poikilohydric organisms capable of desiccation tolerance, analogous to BSC and soil bacteria found in terrestrial arid deserts and in permafrost in polar regions. Other possible early land habitats could have been seasonal or perennial snow banks, debris-rich glacier ice, ice-bearing permafrost (Jakosky et al., 2003; Córdoba-Jabonero et al., 2005; McKay et al., 2013), or protected habitats near the surface such as caves (Boston et al., 2011; Northup et al., 2011).

With increasing dryness, regolith communities would have become discontinuous and gradually replaced by desert pavements. Wind erosion or dust deposition would have 


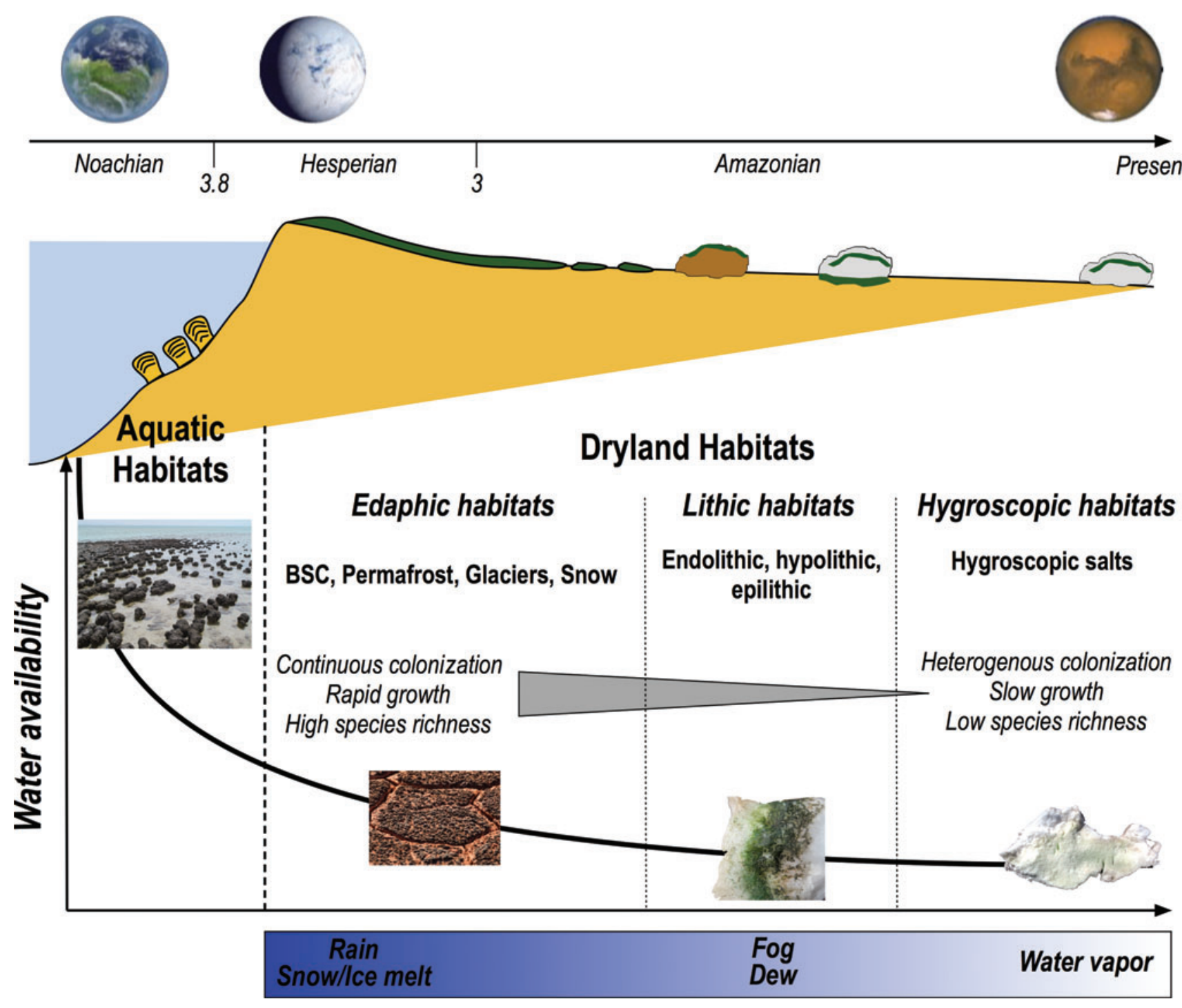

FIG. 3. Proposed sequence of ecological transitions on Mars with increasing dryness, assuming an early colonization of land. After the disappearance of aquatic environments, land habitats (edaphic, lithic, and lastly hygroscopic) would still be available, based on different sources of atmospheric water. (Color graphics available online at www.liebertonline.com/ast)

slowly erased any surface expression of such communities through dispersal or burial, although transient climate excursions toward wetter conditions, driven for example by orbital fluctuations, could have reactivated the regolith communities for relatively short periods. At this point, longterm active metabolism would have been largely constrained to lithobiontic communities, both in hypolithic and endolithic habitats selected based upon certain physical properties of the rock substrate, such as color, opacity, size, and porosity (e.g., Friedmann and Koriem, 1989; McKay et al., 1992). If members of these lithic communities were light-dependent, relatively translucent rocks such as sandstone, calcite, ignimbrite, gypsum, quartz, or dolomite would have been suitable for colonization, such as is observed in practically all deserts on Earth (Friedmann, 1982; Friedmann and OcampoFriedmann, 1984; Wierzchos et al., 2011, 2013; Pointing and Belnap, 2012; DiRuggiero et al., 2013). In the case of lightindependent communities, other lithic substrates might have been available, such as opaque rocks. Yet the strong selective pressure to colonize lithic habitats ought to be independent of sources of energy and nutrients and instead should apply to forms of life that rely on atmospheric sources of water.

Finally, the last habitat for life near the surface would have been the interior of hygroscopic salt crusts, which could trigger the condensation of liquid water via deliquescence at relative humidity $(\mathrm{RH})$ conditions well below the atmospheric condensation point. At the same time, the deliquescent brines would have acted as antifreeze, depressing the freezing point of water, and the interior of the salt substrate would have provided shelter against UV radiation. Analogues of such salt communities would be the endolithic communities found in fossil salars in the hyperarid core of the Atacama Desert (Wierzchos et al., 2006; Davila et al., 2010).

The proposed sequence of ecological transitions with increasing dryness is based on global trends observed in both hot and cold deserts on Earth. Our analysis does not preclude the existence today, or in the recent past, of specialized habitats typical of polar desert environments, such as 
debris-rich ice ( Jakosky et al., 2003; Córdoba-Jabonero et al., 2005; McKay et al., 2013), but such habitats would require local sources of water and are constrained to high latitudes, which are permanently cold, an additional constraint to life.

\section{Implications for Recent Martian Habitability}

If hygroscopic habitats such as those found in the Atacama Desert represent the last possible outposts for life under extremely dry conditions, then we can use them to approximate the last time when Mars might have been a habitable planet.

The habitability of hygroscopic salt crusts depends critically on the abundance of water in the atmosphere and in the nature of the salt substrate, which determines its deliquescence properties and the eutectic temperature and water activity of the deliquescence solution (Davila et al., 2010). Water activity is the relevant parameter that links liquid water and habitability. Assuming long-term equilibrium conditions and the average temperature and $\mathrm{RH}$ on the martian surface, the water activity of an aqueous solution on present-day Mars should fall well below the conditions for habitability for any terrestrial organisms (e.g., Kminek et al., 2010; Rummel et al., 2014). However, for a more precise assessment of habitability we must consider that the planet is not in equilibrium and determinations of water activity need to be done at the scale of the environment experienced by microorganisms, where environmental conditions can depart significantly from the average (McKay and Friedmann, 1985; Nienow et al., 1988a, 1988b; Davila et al., 2008; Wierzchos et al., 2012a; Meckenstock et al., 2014). Temperature and RH fluctuations on Mars could promote transient deliquescence inside salt crusts with low eutectic points (Chevrier et al., 2009; Davila et al., 2010; Martín-Torres et al., 2015). For salt with very low eutectic points such as perchlorate, the water activity of the resulting transient solution-in addition to its temperature-would still fall below the known threshold for growth, but other salts such as $\mathrm{NaCl}$ would produce more benign deliquescent brines. These examples serve to illustrate the limitations that arise when assessing habitability assuming only large-scale equilibrium conditions.

A comparison of the abundance of atmospheric water on Mars and in the driest regions on Earth might give an idea of how prevalent and intense deliquescent events might be on the planet. Most of the martian water inventory is sequestered in the polar layered terrains and in the near-surface regolith at latitudes above 30-40 (e.g., Head et al., 2003; Feldman, 2004; Byrne et al., 2009; Carr and Head, 2010; Kadish and Head, 2011). The median column of precipitable water vapor (PWV) is between $<3$ and 100 precipitable micrometers (pr- $\mu \mathrm{m}$ ) planetwide (Jakosky and Farmer, 1982; Haberle et al., 2001). Climate simulations predict that increased polar summer insolation during high obliquity leads to a water cycle that is much more intense than today's, with a column water abundance up to $3000 \mathrm{pr}-\mu \mathrm{m}$ above the northern polar cap around summer solstice and about $50 \mathrm{pr}-\mu \mathrm{m}$ in the summer tropics (Jakosky and Carr, 1985; Forget et al., 2006). Assuming an average obliquity of $40^{\circ}$ during the last 3 billion years, the long-term water content of the lower atmosphere could be 2 orders of magnitude higher than it is at present (Mellon and Jakosky,
1995), and there could be $>1000 \mathrm{pr}-\mu \mathrm{m}$ of atmospheric water at midlatitudes and low latitudes during recent highobliquity (i.e., $45^{\circ}$ ) periods (Jakosky and Carr, 1985). In comparison, the median column of PWV above the Andean plateau in the Atacama Desert is approximately $1200 \mathrm{pr}-\mu \mathrm{m}$ at an elevation of $5000 \mathrm{~m}$ (Giovanelli et al., 2001; Tremblin et al., 2012), equivalent to the PWV in the hyperarid core of the desert where deliquescence-driven microbial ecosystems are found. For completeness, we note that the lowest PWV reported so far on our planet is near the South Pole and ranges between 100 and $800 \mathrm{pr}-\mu \mathrm{m}$, with minimum annual values as low as $30 \mathrm{pr}-\mu \mathrm{m}$ (Buravo et al., 1986; Chamberlain et al., 2000). Hence, as a first approximation the water abundance in the present-day martian atmosphere is lower than in the driest regions on Earth by a factor of 10-100, but during high obliquity it is comparable to levels measured in the hyperarid core of the Atacama Desert. Assumingrather arbitrarily - that a PWV of $1000 \mathrm{pr}-\mu \mathrm{m}$ represents the minimum atmospheric water abundance that can sustain deliquescence-driven microbial ecosystems, the abundance of water on a comparison of the martian surface to the driest deserts on Earth suggests that the habitability window in this type of substrate might have closed relatively recently, perhaps during the late Amazonian, or it may possibly still be open.

\section{Conclusions}

Currently, the search for ancient aqueous environments as repositories of possible evidence of life is the primary focus of robotic missions to Mars. However, the colonization of land by putative martian microorganisms could have opened a lasting evolutionary trajectory for life independent of aquatic habitats. The ecological transitions that occur in Earth's deserts with increasing dryness can inform us as to where the last martian near-surface ecosystems may have existed or still exist. In analogy with terrestrial dryland ecosystems, the physical properties of habitats with regard to water retention, rather than the physiological adaptations of microorganisms, could have directed the late-stage evolution of life on Mars. As is the case for Earth's driest regions, the last possible sources of water for life on Mars would have been the deliquescence of hygroscopic salt crusts, and this window of habitability might have closed relatively recently or may still be open. As such, and in retrospect, dry regolith samples analyzed by the Viking landers might not have been the best substrates to search for active (or extinct) biology. Future robotic missions would be advised to prioritize the study of lithic substrates.

\section{Acknowledgments}

A.F.D. acknowledges funding from the NASA Exobiology Program (Grant NNX12AD61G) and the NASA Astrobiology Institute (NAI Grant NNX15BB01A to the SETI Institute). D.S.M. acknowledges funding for this work from ERC Advanced Grant 339231. We thank Kim WarrenRhodes, Chris McKay, and Henry Sun for helpful discussions and for providing some of the images in Fig. 1.

\section{Author Disclosure Statement}

No competing financial interests exist. 


\section{References}

Acuna, M.H., Connerney, J.E.P., Wasilewski, P., Lin, R.P., Anderson, K.A., Carlson, C.W., McFadden, J., Curtis, D.W., Mitchell, D., Reme, H., Mazelle, C., Sauvaud, J.A., D’Uston, C., Cros, A., Medale, J.L., Bauer, S.J., Cloutier, P., Mayhew, M., Winterhalter, D., and Ness, N.F. (1998) Magnetic field and plasma observations at Mars: initial results of the Mars Global Surveyor mission. Science 279:1676-1680.

Allen, M.E. (1997) Studies on biomass, productivity and nanoclimate of desert pavement cyanobacteria. PhD thesis, Florida State University, Tallahassee, FL.

Alpert, P. (2005) The limits and frontiers of desiccation-tolerant life. Integr Comp Biol 45:685-695.

Alpert, P. and Oechel, W.C. (1985) Carbon balance limits the micro-distribution of Grimmia laevigata, a dessicationtolerant plant. Ecology 66:660-669.

Al-Thani, R.F. (2014) Hypolithic cyanobacteria colonization of quartz at south desert. OnLine Journal of Biological Sciences 14:57-63.

Amundson, R. (2001) The carbon budget in soils. Annu Rev Earth Planet Sci 29:535-562.

Azúa-Bustos, A., González-Silva, C., Mancilla, R.A., Salas, L., Gómez-Silva, B., McKay, C.P., and Vicuña, R. (2011) Hypolithic cyanobacteria supported mainly by fog in the coastal range of the Atacama Desert. Microb Ecol 61:568-581.

Battistuzzi, F.U. and Hedges, S.B. (2009) A major clade of prokaryotes with ancient adaptations to life on land. Mol Biol Evol 26:335-343.

Belnap, J. and Lange, O.L. (2003) Biological Soil Crusts: Structure, Function, and Management, edited by J. Belnap and O.L. Lange, Springer, Berlin.

Beraldi-Campesi, H. (2013) Early life on land and the first terrestrial ecosystems. Ecol Process 2, doi:10.1186/21921709-2-1.

Bibring, J.-P., Langevin, Y., Mustard, J.F., Poulet, F., Arvidson, R., Gendrin, A., Gondet, B., Mangold, N., Pinet, P., Forget, F., Berthé, M., Bibring, J.-P., Gendrin, A., Gomez, C., Gondet, B., Jouglet, D., Poulet, F., Soufflot, A., Vincendon, M., Combes, M., Drossart, P., Encrenaz, T., Fouchet, T., Merchiorri, R., Belluci, G., Altieri, F., Formisano, V., Capaccioni, F., Cerroni, P., Coradini, A., Fonti, S., Korablev, O., Kottsov, V., Ignatiev, N., Moroz, V., Titov, D., Zasova, L., Loiseau, D., Mangold, N., Pinet, P., Douté, S., Schmitt, B., Sotin, C., Hauber, E., Hoffmann, H., Jaumann, R., Keller, U., Arvidson, R., Mustard, J.F., Duxbury, T., Forget, F., and Neukum, G. (2006) Global mineralogical and aqueous Mars history derived from OMEGA/Mars Express data. Science 312:400-404.

Boston, P.J., Spilde, M.N., Northup, D.E., Melim, L.A., Soroka, D.S., Kleina, L.G., Lavoie, K.H., Hose, L.D., Mallory, L.M., Dahm, C.N., Crossey, L.J., and Schelble, R.T. (2011) Cave biosignature suites: microbes, minerals, and Mars. Astrobiology $1: 1-7$.

Buravo, L.P., Gromov, V.D., Lukyanchikova, N.I., and Sholomitskii, G.B. (1986) Low humidity and submillimeter transparency above the Vostok Antartic Station. Soviet Astronomy Letters 12:339-341.

Byrne, S., Dundas, C.M., Kennedy, M.R., Mellon, M.T., McEwen, A.S., Cull, S.C., Daubar, I.J., Shean, D.E., Seelos, K.D., Murchie, S.L., Cantor, B.A., Arvidson, R.E., Edgett, K.S., Reufer, A., Thomas, N., Harrison, T.N., Posiolova, L.V., and Seelos, F.P. (2009) Distribution of mid-latitude ground ice on Mars from new impact craters. Science 325:1674-1676.
Carr, M.H. and Head, J.W. (2010) Geologic history of Mars. Earth Planet Sci Lett 294:185-203.

Carr, M.H. and Head, J.W. (2015) Martian surface/near-surface water inventory: sources, sinks, and changes with time. Geophys Res Lett 42:726-732.

Cary, S.C., McDonald, I.R., Barrett, J.E., and Cowan, D.A. (2010) On the rocks: the microbiology of Antarctic Dry Valley soils. Nat Rev Microbiol 8:129-138.

Chamberlain, M.A., Ashley, M.C.B., Burton, M.G., Phillips, A., Storey, J.W.V., and Harper, D.A. (2000) Mid-infrared observing conditions at the South Pole. Astrophys J 535:501511.

Chevrier, V.F., Hanley, J., and Altheide, T.S. (2009) Stability of perchlorate hydrates and their liquid solutions at the Phoenix landing site, Mars. Geophys Res Lett 36:L10202.

Coe, K.K., Belnap, J., and Sparks, J.P. (2012) Precipitationdriven carbon balance controls survivorship of desert biocrust mosses. Ecology 93:1626-1636.

Colesie, C., Gommeaux, M., Green, T.G.A., and Büdel, B. (2013) Biological soil crusts in continental Antarctica: Garwood Valley, southern Victoria Land, and Diamond Hill, Darwin Mountains region. Antarct Sci 9:1-9.

Córdoba-Jabonero, C., Zorzano, M.-P., Selsis, F., Patel, M.R., and Cockell, C.S. (2005) Radiative habitable zones in martian polar environments. Icarus 175:360-371.

Crits-Christoph, A., Robinson, C.K., Barnum, T., Fricke, W.F., Davila, A.F., Jedynak, B., McKay, C.P., and Diruggiero, J. (2013) Colonization patterns of soil microbial communities in the Atacama Desert. Microbiome 1, doi:10.1186/2049-2618$1-28$.

Davila, A.F., Gómez-Silva, B., de los Ríos, A., Ascaso, C., Olivares, H., McKay, C.P., and Wierzchos, J. (2008) Facilitation of endolithic microbial survival in the hyperarid core of the Atacama Desert by mineral deliquescence. J Geophys Res 113, doi:10.1029/2007JG000561.

Davila, A.F., Duport, L.G., Melchiorri, R., Jänchen, J., Valea, S., de los Ríos, A., Fairén, A.G., Möhlmann, D., McKay, C.P., Ascaso, C., and Wierzchos, J. (2010) Hygroscopic salts and the potential for life on Mars. Astrobiology 10:617-628.

Davila, A.F., Hawes, I., Ascaso, C., and Wierzchos, J. (2013) Salt deliquescence drives photosynthesis in the hyperarid Atacama Desert. Environ Microbiol Rep 5:583-587.

Davila, A.F., Hawes, I., Araya, J.G., Gelsinger, D.R., DiRuggiero, J., Ascaso, C., Osano, A., and Wierzchos, J. (2015) In situ metabolism in halite endolithic microbial communities of the hyperarid Atacama Desert. Front Microbiol 6, doi:10.3389/fmicb.2015.01035.

de los Ríos, A., Valea, S., Ascaso, C., Davila, A.F., Kastovsky, J., McKay, C.P., and Wierzchos, J. (2010) Comparative analysis of the microbial communities inhabiting halite evaporites of the Atacama Desert. Int Microbiol 13:79-89.

Delgado-Baquerizo, M., Maestre, F.T., Gallardo, A., Bowker, M.A., Wallenstein, M.D., Quero, J.L., Ochoa, V., Gozalo, B., García-Gómez, M., Soliveres, S., García-Palacios, P., Berdugo, M., Valencia, E., Escolar, C., Arredondo, T., BarrazaZepeda, C., Bran, D., Carreira, J.A., Chaieb, M., Conceição, A.A., Derak, M., Eldridge, D.J., Escudero, A., Espinosa, C.I., Gaitán, J., Gatica, M.G., Gómez-González, S., Guzman, E., Gutiérrez, J.R., Florentino, A., Hepper, E., Hernández, R.M., Huber-Sannwald, E., Jankju, M., Liu, J., Mau, R.L., Miriti, M., Monerris, J., Naseri, K., Noumi, Z., Polo, V., Prina, A., Pucheta, E., Ramírez, E., Ramírez-Collantes, D.A., Romão, R., Tighe, M., Torres, D., Torres-Díaz, C., Ungar, E.D., Val, J., Wamiti, W., Wang, D., and Zaady, E. (2013) Decoupling 
of soil nutrient cycles as a function of aridity in global drylands. Nature 502:672-676.

DiRuggiero, J., Wierzchos, J., Robinson, C.K., Souterre, T., Ravel, J., Artieda, O., Souza-Egipsy, V., and Ascaso, C. (2013) Microbial colonisation of chasmoendolithic habitats in the hyper-arid zone of the Atacama Desert. Biogeosciences 10:2439-2450.

Ehlmann, B.L. and Edwards, C.S. (2014) Mineralogy of the martian surface. Annu Rev Earth Planet Sci 42:291-315.

Ewing, S.A., Macalady, J.L., Warren-Rhodes, K., McKay, C.P., and Amundson, R. (2008) Changes in the soil C cycle at the arid-hyperarid transition in the Atacama Desert. $J$ Geophys Res 113, doi:10.1029/2007JG000495.

Fairén, A.G., Schulze-Makuch, D., Rodríguez, A.P., Fink, W., Davila, A.F., Uceda, E.R., Furfaro, R., Amils, R., and McKay, C.P. (2009) Evidence for Amazonian acidic liquid water on Mars-a reinterpretation of MER mission results. Planet Space Sci 57:276-287.

Feldman, W.C. (2004) Global distribution of near-surface hydrogen on Mars. J Geophys Res 109, doi:10.1029/ 2003JE002160.

Forget, F., Haberle, R.M., Montmessin, F., Levrard, B., and Head, J.W. (2006) Formation of glaciers on Mars by atmospheric precipitation at high obliquity. Science 311:368-371.

Friedmann, E. and Ocampo-Friedmann, R. (1984) Endolithic microorganisms in extreme dry environments: analysis of a lithobiontic microbial habitat. In Current Perpectives in Microbial Ecology: Proceedings of the Third International Symposium on Microbial Ecology, edited by H. Klug and C. Reddy, American Society of Microbiology, Washington, DC, pp 177-185.

Friedmann, E., Druk, A., and McKay, C. (1994) Limits of life and microbial extinction in the Antarctic desert. Antarctic Journal 29:176-179.

Friedmann, E.I. (1980) Endolithic microbial life in hot and cold deserts. Orig Life 10:223-235.

Friedmann, E.I. (1982) Endolithic microorganisms in the Antarctic cold desert. Science 215:1045-1053.

Friedmann, E.I. and Koriem, A.M. (1989) Life on Mars: how it disappeared (if it was ever there). Adv Space Res 9:167-172.

Friedmann, E.I. and Ocampo-Friedmann, R. (1995) A primitive cyanobacterium as pioneer microorganism for terraforming Mars. Adv Space Res 15:243-246.

Friedmann, E.I., Kappen, L., Meyer, M.A., and Nienow, J.A. (1993) Long-term productivity in the cryptoendolithic microbial community of the Ross Desert, Antarctica. Microb Ecol 25:51-69.

Garcia-Pichel, F. (1998) Solar ultraviolet and the evolutionary history of cyanobacteria. Orig Life Evol Biosph 28:321-347.

Giovanelli, R., Darling, J., Sarazin, M., Yu, J., Harvey, P., Henderson, C., Hoffman, W., Keller, L., Barry, D., Cordes, J., Eikenberry, S., Gull, G., Harrington, J., Smith, J.D., Stacey, G., and Swain, M. (2001) The optical/infrared astronomical quality of high Atacama sites. I. Preliminary results of optical seeing. Publ Astron Soc Pac 113:789-802.

Grotzinger, J.P., Sumner, D.Y., Kah, L.C., Stack, K., Gupta, S., Edgar, L., Rubin, D., Lewis, K., Schieber, J., Mangold, N., Milliken, R., Conrad, P.G., Des Marais, D., Farmer, J., Siebach, K., Calef, F., Hurowitz, J., McLennan, S.M., Ming, D., Vaniman, D., Crisp, J., Vasavada, A., Edgett, K.S., Malin, M., Blake, D., Gellert, R., Mahaffy, P., Wiens, R.C., Maurice, S., Grant, J.A., Wilson, S., Anderson, R.C., Beegle, L., Arvidson, R., Hallet, B., Sletten, R.S., Rice, M., Bell, J., Griffes, J., Ehlmann, B., Anderson, R.B., Bristow, T.F., Dietrich,
W.E., Dromart, G., Eigenbrode, J., Fraeman, A., Hardgrove, C., Herkenhoff, K., Jandura, L., Kocurek, G., Lee, S., Leshin, L.A., Leveille, R., Limonadi, D., Maki, J., McCloskey, S., Meyer, M., Minitti, M., Newsom, H., Oehler, D., Okon, A., Palucis, M., Parker, T., Rowland, S., Schmidt, M., Squyres, S., Steele, A., Stolper, E., Summons, R., Treiman, A., Williams, R., Yingst, A.; MSL Science Team. (2014) A habitable fluvio-lacustrine environment at Yellowknife Bay, Gale Crater, Mars. Science 343, doi:10.1126/science.1242777.

Haberle, R.M., McKay, C.P., Schaeffer, J., Cabrol, N.A., Grin, E.A., Zent, A.P., and Quinn, R. (2001) On the possibility of liquid water on present-day Mars. J Geophys Res 106, doi:10.1029/2000JE001360.

Hallbauer, D.K. and van Warmelo, K.T. (1974) Fossilized plants in thucholite from Precambrian rocks of the Witwatersrand, South Africa. Precambrian Res 1:199-212.

Head, J.W., Mustard, J.F., Kreslavsky, M.A., Milliken, R.E., and Marchant, D.R. (2003) Recent ice ages on Mars. Nature 426:797-802.

Jakosky, B.M. and Carr, M.H. (1985) Possible precipitation of ice at low latitudes of Mars during periods of high obliquity. Nature 315:559-561.

Jakosky, B.M. and Farmer, C.B. (1982) The seasonal and global behavior of water vapor in the Mars atmosphere: complete global results of the Viking Atmospheric Water Detector Experiment. J Geophys Res 87, doi:10.1029/ JB087iB04p02999.

Jakosky, B.M., Nealson, K.H., Bakermans, C., Ley, R.E., and Mellon, M.T. (2003) Subfreezing activity of microorganisms and the potential habitability of Mars' polar regions. Astrobiology 3:343-350.

Kadish, S.J. and Head, J.W. (2011) Impacts into non-polar icerich paleodeposits on Mars: excess ejecta craters, perched craters and pedestal craters as clues to Amazonian climate history. Icarus 215:34-46.

Khan, N., Tuffin, M., Stafford, W., Cary, C., Lacap, D.C., Pointing, S.B., and Cowan, D. (2011) Hypolithic microbial communities of quartz rocks from Miers Valley, McMurdo Dry Valleys, Antarctica. Polar Biol 34:1657-1668.

Kminek, G., Rummel, J.D., Cockell, C.S., Atlas, R., Barlow, N., Beaty, D., Boynton, W., Carr, M., Clifford, S., Conley, C.A., Davila, A.F., Debus, A., Doran, P., Hecht, M., Heldmann, J., Helbert, J., Hipkin, V., Horneck, G., Kieft, T.L., Klingelhoefer, G., Meyer, M., Newsom, H., Ori, G.G., Parnell, J., Prieur, D., Raulin, F., Schulze-Makuch, D., Spry, J.A., Stabekis, P.E., Stackebrandt, E., Vago, J., Viso, M., Voytek, M., Wells, L., and Westall, F. (2010) Report of the COSPAR Mars Special Regions colloquium. Adv Space Res 46:811829.

Lammer, H., Chassefière, E., Karatekin, Ö., Morschhauser, A., Niles, P.B., Mousis, O., Odert, P., Möstl, U.V., Breuer, D., Dehant, V., Grott, M., Gröller, H., Hauber, E., and Pham, L.B.S. (2013) Outgassing history and escape of the martian atmosphere and water inventory. Space Sci Rev 174:113-154.

Lange, O. (1993) Further evidence that activation of net photosynthesis by dry cyanobacterial lichens requires liquid water. Lichenologist 25:175-189.

Martín-Torres, F.J., Zorzano, M.-P., Valentín-Serrano, P., Harri, A.-M., Genzer, M., Kemppinen, O., Rivera-Valentin, E.G., Jun, I., Wray, J., Bo Madsen, M., Goetz, W., McEwen, A.S., Hardgrove, C., Renno, N., Chevrier, V.F., Mischna, M., Navarro-González, R., Martínez-Frías, J., Conrad, P., McConnochie, T., Cockell, C., Berger, G., Vasavada, A.R., Sumner, D., and Vaniman, D. (2015) Transient liquid water 
and water activity at Gale crater on Mars. Nat Geosci 8: 357-361.

McKay, C.P. and Davis, W.L. (1991) Duration of liquid water habitats on early Mars. Icarus 90:214-221.

McKay, C.P. and Friedmann, E.I. (1985) The cryptoendolithic microbial environment in the Antarctic cold desert: temperature variations in nature. Polar Biol 4:19-25.

McKay, C.P., Imre Friedman, E., Wharton, R.A., and Davies, W.L. (1992) History of water on Mars: a biological perspective. Adv Space Res 12:231-238.

McKay, C.P., Stoker, C.R., Glass, B.J., Dave, A.I., Davila, A.F., Heldmann, J.L., Marinova, M.M., Fairen, A.G., Quinn, R.C., Zacny, K.A., Paulsen, G., Smith, P.H., Parro, V., Andersen, D.T., Hecht, M.H., Lacelle, D., Pollard, W.H., and Davé, A.I. (2013) The Icebreaker Life mission to Mars: a search for biomolecular evidence for life. Astrobiology 13:334-354.

Meckenstock, R.U., von Netzer, F., Stumpp, C., Lueders, T., Himmelberg, A.M., Hertkorn, N., Schmitt-Kopplin, P., Harir, M., Hosein, R., Haque, S., and Schulze-Makuch, D. (2014) Water droplets in oil are microhabitats for microbial life. Science 345:673-676.

Mellon, M.T. and Jakosky, B.M. (1995) The distribution and behavior of martian ground ice during past and present epochs. J Geophys Res 100, doi:10.1029/95JE01027.

Mossman, D.J., Minter, W.E.L., Dutkiewicz, A., Hallbauer, D.K., George, S.C., Hennigh, Q., Reimer, T.O., and Horscroft, F.D. (2008) The indigenous origin of Witwatersrand “carbon." Precambrian Res 164:173-186.

Mustard, J.F., Murchie, S.L., Pelkey, S.M., Ehlmann, B.L., Milliken, R.E., Grant, J.A., Bibring, J.-P., Poulet, F., Bishop, J., Dobrea, E.N., Roach, L., Seelos, F., Arvidson, R.E., Wiseman, S., Green, R., Hash, C., Humm, D., Malaret, E., McGovern, J.A., Seelos, K., Clancy, T., Clark, R., Des Marais, D., Izenberg, N., Knudson, A., Langevin, Y., Martin, T., McGuire, P., Morris, R., Robinson, M., Roush, T., Smith, M., Swayze, G., Taylor, H., Titus, T., and Wolff, M. (2008) Hydrated silicate minerals on Mars observed by the Mars Reconnaissance Orbiter CRISM instrument. Nature 454: 305-309.

Nienow, J.A., McKay, C.P., and Friedmann, E.I. (1988a) The cryptoendolithic microbial environment in the Ross Desert of Antarctica: mathematical models of the thermal regime. $\mathrm{Mi}$ crob Ecol 16:253-270.

Nienow, J.A., McKay, C.P., and Friedmann, E.I. (1988b) The cryptoendolithic microbial environment in the Ross Desert of Antarctica: light in the photosynthetically active region. $\mathrm{Mi}$ crob Ecol 16:271-289.

Northup, D.E., Melim, L.A., Spilde, M.N., Hathaway, J.J.M., Garcia, M.G., Moya, M., Stone, F.D., Boston, P.J., Dapkevicius, M.L.N.E., and Riquelme, C. (2011) Lava cave microbial communities within mats and secondary mineral deposits: implications for life detection on other planets. Astrobiology 11:601-618.

Noy-Meir, I. (1973) Desert ecosystems: environment and producers. Аnnu Rev Ecol Syst 4:25-51.

Pattanaik, B., Schumann, R., and Karsten, U. (2007) Effects of ultraviolet radiation on cyanobacteria and their protective mechanisms. In Algae and Cyanobacteria in Extreme Environments, edited by J. Seckbach, Springer, Dordrecht, the Netherlands, pp 29-45.

Pointing, S.B. and Belnap, J. (2012) Microbial colonization and controls in dryland systems. Nat Rev Microbiol 10:654.

Pointing, S.B., Warren-Rhodes, K.A., Lacap, D.C., Rhodes, K.L., and McKay, C.P. (2007) Hypolithic community shifts occur as a result of liquid water availability along environmental gradients in China's hot and cold hyperarid deserts. Environ Microbiol 9:414-424.

Pointing, S.B., Chan, Y., Lacap, D.C., Lau, M.C.Y., Jurgens, J.A., and Farrell, R.L. (2009) Highly specialized microbial diversity in hyper-arid polar desert. Proc Natl Acad Sci USA 106:19964-19969.

Potts, M. (1994) Desiccation tolerance of prokaryotes. Microbiol Rev 58:755-805.

Prave, A.R. (2002) Life on land in the Proterozoic: evidence from the Torridonian rocks of northwest Scotland. Geology 30:811-814.

Proctor, M.C.F., Oliver, M.J., Wood, A.J., Alpert, P., Stark, L.R., Cleavitt, N.L., and Mishler, B.D. (2007) Desiccation tolerance in bryophytes: a review. Bryologist 110:595-621.

Robinson, C.K., Wierzchos, J., Black, C., Crits-Christoph, A., Ma, B., Ravel, J., Ascaso, C., Artieda, O., Valea, S., Roldán, M., Gómez-Silva, B., and DiRuggiero, J. (2015) Microbial diversity and the presence of algae in halite endolithic communities are correlated to atmospheric moisture in the hyperarid zone of the Atacama Desert. Environ Microbiol 17: 299-315.

Rodríguez, J.A.P., Gulick, V.C., Baker, V.R., Platz, T., Fairén, A.G., Miyamoto, H., Kargel, J.S., Rice, J.W., and Glines, N. (2014) Evidence for Middle Amazonian catastrophic flooding and glaciation on Mars. Icarus 242:202-210.

Rodríguez, J.A.P., Platz, T., Gulick, V., Baker, V.R., Fairén, A.G., Kargel, J., Yan, J., Miyamoto, H., and Glines, N. (2015) Did the martian outflow channels mostly form during the Amazonian period? Icarus 257:387-395.

Rummel, J.D., Beaty, D.W., Jones, M.A., Bakermans, C., Barlow, N.G., Boston, P.J., Chevrier, V.F., Clark, B.C., de Vera, J.-P.P., Gough, R.V., Hallsworth, J.E., Head, J.W., Hipkin, V.J., Kieft, T.L., McEwen, A.S., Mellon, M.T., Mikucki, J.A., Nicholson, W.L., Omelon, C.R., Peterson, R., Roden, E.E., Sherwood Lollar, B., Tanaka, K.L., Viola, D., and Wray, J.J. (2014) A new analysis of Mars "Special Regions": findings of the second MEPAG Special Regions Science Analysis Group (SR-SAG2). Astrobiology 14:887968.

Rye, R. and Holland, H.D. (2000) Life associated with a 2.76 Ga ephemeral pond?: evidence from Mount Roe \#2 paleosol. Geology 28:483-486.

Sun, H. (2013) Endolithic microbial life in extreme cold climate: snow is required, but perhaps less is more. Biology 2: 693-701.

Tremblin, P., Schneider, N., Minier, V., Durand, G.A., and Urban, J. (2012) Worldwide site comparison for submillimetre astronomy. Astron Astrophys 548:A65.

Warren-Rhodes, K.A., Rhodes, K.L., Pointing, S.B., Ewing, S.A., Lacap, D.C., Gómez-Silva, B., Amundson, R., Friedmann, E.I., and McKay, C.P. (2006) Hypolithic cyanobacteria, dry limit of photosynthesis, and microbial ecology in the hyperarid Atacama Desert. Microb Ecol 52:389-398.

Warren-Rhodes, K.A., Rhodes, K.L., Boyle, L.N., Pointing, S.B., Chen, Y., Liu, S., Zhuo, P., and McKay, C.P. (2007) Cyanobacterial ecology across environmental gradients and spatial scales in China's hot and cold deserts. FEMS Microbiol Ecol 61:470-482.

Warren-Rhodes, K.A., McKay, C.P., Boyle, L.N., Wing, M.R., Kiekebusch, E.M., Cowan, D.A., Stomeo, F., Pointing, S.B., Kaseke, K.F., Eckardt, F., Henschel, J.R., Anisfeld, A., Seely, M., and Rhodes, K.L. (2013) Physical ecology of hypolithic communities in the central Namib Desert: the role of fog, 
rain, rock habitat, and light. J Geophys Res: Biogeosciences 118:1451-1460.

Watanabe, Y., Martini, J.E., and Ohmoto, H. (2000) Geochemical evidence for terrestrial ecosystems 2.6 billion years ago. Nature 408:574-578.

Wierzchos, J., de los Ríos, A., Sancho, L.G., and Ascaso, C. (2004) Viability of endolithic micro-organisms in rocks from the McMurdo Dry Valleys of Antarctica established by confocal and fluorescence microscopy. J Microsc 216(Pt 1): $57-61$.

Wierzchos, J., Sancho, L.G., and Ascaso, C. (2005) Biomineralization of endolithic microbes in rocks from the McMurdo Dry Valleys of Antarctica: implications for microbial fossil formation and their detection. Environ Microbiol 7:566-575.

Wierzchos, J., Ascaso, C., and McKay, C.P. (2006) Endolithic cyanobacteria in halite rocks from the hyperarid core of the Atacama Desert. Astrobiology 6:415-422.

Wierzchos, J., Cámara, B., de los Ríos, A., Davila, A.F., Sánchez Almazo, I.M., Artieda, O., Wierzchos, K., Gómez-Silva, B., McKay, C., and Ascaso, C. (2011) Microbial colonization of Ca-sulfate crusts in the hyperarid core of the Atacama Desert: implications for the search for life on Mars. Geobiology 9:44-60.

Wierzchos, J., Davila, A., Sánchez-Almazo, I.M., Hajnos, M., Swieboda, R., and Ascaso, C. (2012a) Novel water source for endolithic life in the hyperarid core of the Atacama Desert. Biogeosciences 9:3071-3098.

Wierzchos, J., de los Ríos, A., and Ascaso, C. (2012b) Microorganisms in desert rocks: the edge of life on Earth. Int Microbiol 15:173-183.
Wierzchos, J., Davila, A.F., Artieda, O., Cámara-Gallego, B., de los Ríos, A., Nealson, K.H., Valea, S., Teresa GarcíaGonzález, M., and Ascaso, C. (2013) Ignimbrite as a substrate for endolithic life in the hyper-arid Atacama Desert: implications for the search for life on Mars. Icarus 224:334-346.

Ziolkowski, L.A., Wierzchos, J., Davila, A.F., and Slater, G.F. (2013) Radiocarbon evidence of active endolithic microbial communities in the hyperarid core of the Atacama Desert. Astrobiology 13:606-616.

\section{Address correspondence to: Alfonso F. Davila NASA Ames Research Center MS 245-3 \\ Moffett Field, CA 95043 \\ E-mail: adavila@seti.org}

Submitted 7 July 2015 Accepted 11 October 2015

$\begin{aligned} & \text { Abbreviations Used } \\ & \mathrm{AI}=\text { Aridity Index } \\ & \mathrm{BSC}=\text { biological soil crusts } \\ & \mathrm{OC}=\text { organic carbon } \\ & \mathrm{PWV}=\text { precipitable water vapor } \\ & \mathrm{RH}=\text { relative humidity }\end{aligned}$

